\title{
Trace element composition and cathodoluminescence properties of kimberlitic zircons
}

\author{
Belousova, E.A ${ }^{1}$, Griffin, W.L 1,2 and O'Reilly, S.Y.1 \\ 1. GEMOC National Key Centre, School of Earth Sciences, Macquarie University, NSW 2109, Australia. \\ 2. CSIRO Exploration and Mining, P.O. Box 136, North Ryde, NSW 2113, Australia
}

Zircon is a minor mineral in kimberlites, and is recognised as a member of the low-Cr suite of mantle-derived megacryst minerals. The frequent occurrence of zircon in kimberlites suggests that, by finding specific characteristic features of kimberlite zircons, it may be used as an indicator mineral during diamond exploration. However, the morphology of the kimberlitic zircon grains does not show clearly defined features peculiar to the zircon of kimberlites. Therefore, cathodoluminescence (CL) microscopy and laser ablation ICPMS analysis were used to study the internal structure and chemical composition of zircon crystals from kimberlites of South Africa, Russia, Botswana and Australia.

Zoning revealed by CL ranges from fine oscillatory to broad homogeneous cores and overgrowths predominantly in bluish colours; yellow CL colours are much less common. Samples or zones with yellow CL have higher U, Th, Y, and REE than those with blue-violet CL. We suggest that variations in the concentrations of a range of trace elements lead to different amounts of lattice defects, creating the possibility for different levels of direct excitation of luminescence centres, and therefore different CL colours. All crustal zircons studied so far exhibit only dull yellow CL colours.

LAM-ICPMS data show that kimberlite zircons have distinctive trace element patterns, with well defined ranges for REE, Y, U, Th and P (Fig. 1). Low U contents (commonly 6-20 ppm) and REE contents $(\Sigma \mathrm{REE}<50 \mathrm{ppm})$, as well as chondrite-normalised REE patterns with low and flat HREE (Fig. 1), are characteristic of kimberlite zircons and distinguish them from crustal zircons.

South African kimberlitic zircons are the best represented group; 71 grains from 13 different kimberlite pipes have been studied. Their averaged abundances of heavy REE, Y, Sn, Hf, $\mathrm{Mn}, \mathrm{Ti}$ and $\mathrm{Pb}$ (Fig. 1) are slightly higher than those of kimberlitic zircons from on-craton fields of Yakutia and Australia. However, the averaged trace element pattern of Southern African zircons is distinct (lower and flatter) from those of zircons from off-craton kimberlite pipes of Yakutia and old Jwaneng zircons (Botswana).

Yakutian kimberlitic zircons (Russia) are represented by 39 grains from 19 kimberlite pipes in 8 kimberlite fields. The trace element signatures of the Yakutian zircons divide them into two well defined groups, belonging to on-craton and off-craton kimberlite fields (Fig. 2). On-craton zircons originate from areas with the thick Archaean lithosphere and low geotherm which are required for high diamond prospectivity. The trace element patterns of on-craton zircons are similar to those of South African and Australian kimberlitic zircons (Fig. 1). Furthermore, the trace element abundances and the slope of the trace element patterns decreases towards the inner part of the Archaean craton. Zircons from the off-craton fields, in contrast, have higher concentrations of almost all trace elements (Fig. 1,2).

Two zircon populations have been previously described (Kinny et al., 1989) from the Jwaneng kimberlite in Botswana. One gives Permian $206 \mathrm{~Pb} / 238 \mathrm{U}$ dates, close to the time of kimberlite eruption; the other yields much older U-Pb dates (2100 to $2800 \mathrm{My})$. These two groups are morphologically indistinguishable, but can be easily identified by differences in their cathodoluminescence colours and trace element composition (Fig. 1). Old Jwaneng zircons typically have several times higher contents of most trace elements, but lower $\mathrm{U}, \mathrm{Th}, \mathrm{Sr}, \mathrm{Ta}$ and $\mathrm{Nb}$ values; they also show pronounced positive Ce anomalies, as well as blue CL colours. In contrast, all zircons of the younger generation have yellow CL colours. Both generations have trace element patterns that are different in several respects from those of most kimberlitic 




Fig. 1 Trace element patterns of kimberlitic zircons (averaged data) from different sources

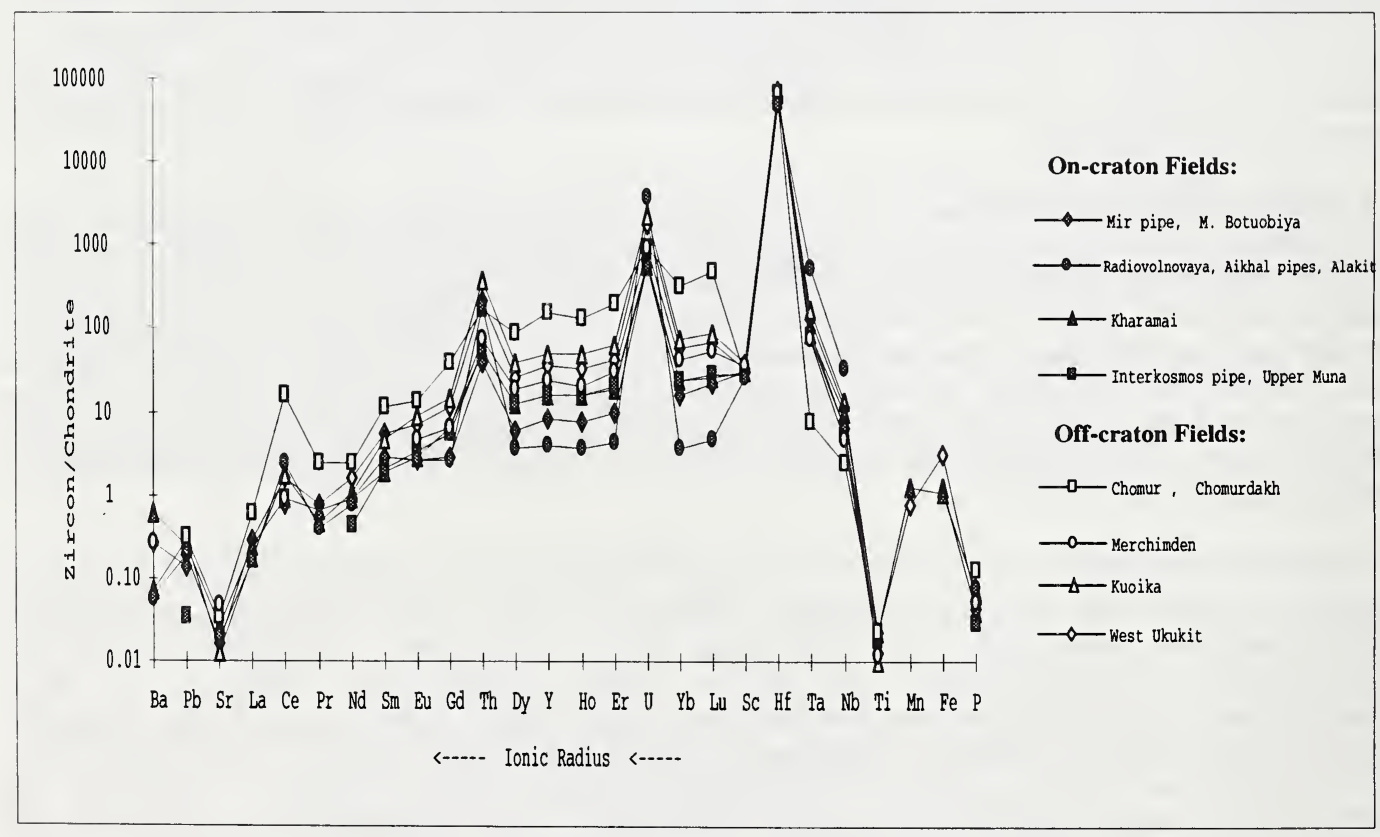

Fig. 2 Trace element patterns of zircons from Yakutian kimberlite fields 
zircons (Fig 1, 3): the older population has higher REE concentrations, while the younger one shows slightly higher $\mathrm{U}, \mathrm{La}, \mathrm{Sr}, \mathrm{Ta}$ and $\mathrm{Nb}$ values and a much flatter REE pattern. The data suggest that the Jwaneng zircons may not be mantle-derived xenocrysts, but have been entrained from the lower crust by the ascending kimberlite magma.

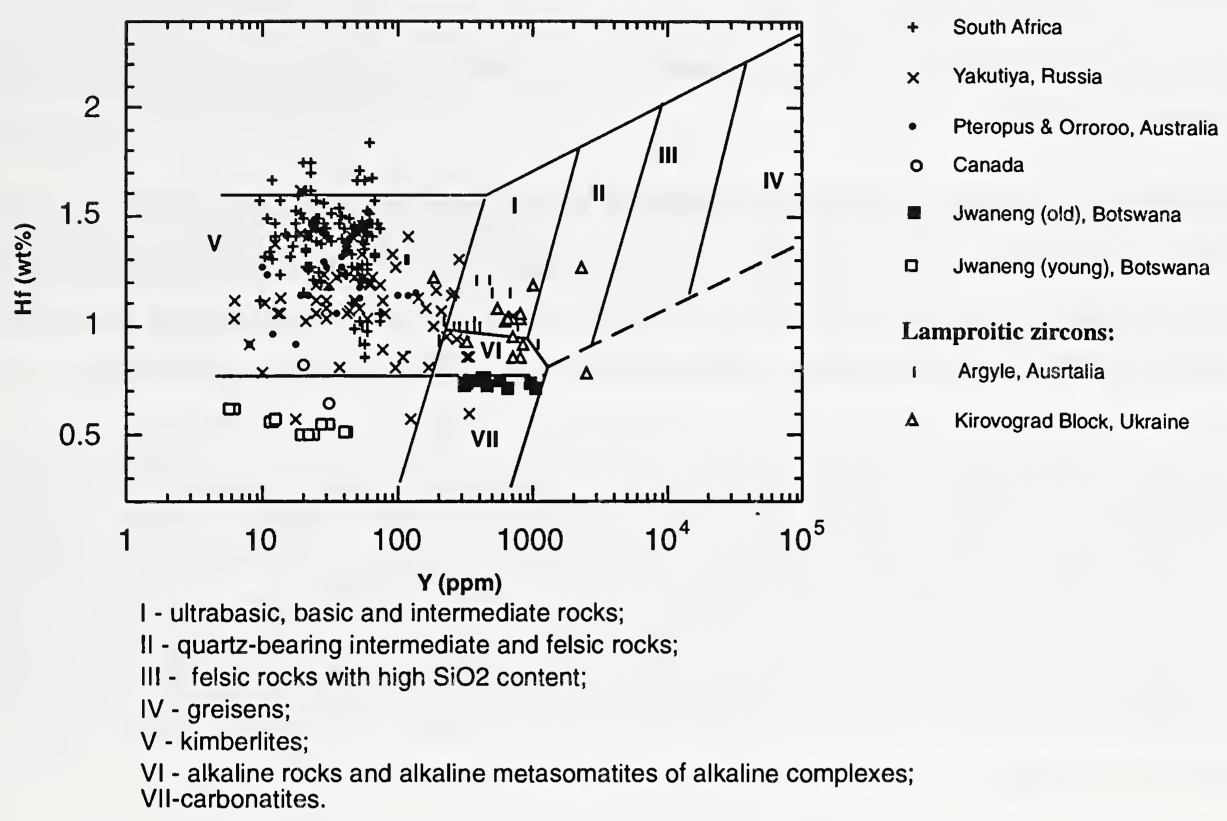

Fig. 3 The fields of zircon composition after Shnyukov et al., 1997.

Australian kimberlitic zircons are represented by 20 grains from two small kimberlite bodies: Orroroo, South Australia and Pteropus, Kimberley. The Orroroo kimberlite pipe has a low diamond content, while Pteropus is barren. Cathodoluminescence colours range from yellow through pink to bluish and dark violet. Trace element data are very similar for both pipes and are in a good agreement with data obtained for other kimberlite localities (Fig. 1).

Kimberlitic zircons from Yakutia, South Africa and Australia form a distinctive field on Fig. 3 (Hf versus Y) relative to the fields of zircon composition from different rock types (Shnyukov et al., 1997) and are located well off the main trend defined by crustal zircons. However, the field of Yakutian zircons is shifted to higher Y and lower Hf concentrations relative to South African and Australian zircons. Several points fall in the fields of crustal zircons, which might suggest that these grains are xenocrysts and were assimilated from crustal rocks. In contrast, zircons from lamproites (Argyle, Australia, Kirovograd Block of the Ukraine) show their crustal origin, falling in the field of zircons from ultrabasic, basic and intermediate rocks (Fig. 3).

\section{References:}

Kinny, P. D., and Compston, W., 1989, Archaean mantle xenocrysts in a Permian kimberlite: two generations of kimberlitic zircon in Jwaneng: Special Publication Geological Society of Australia, 14, 833-842.

Shnyukov, S.E., Andreev, A.V., Savenok S.P., 1997, Admixture elements in zircons and apatites: a tool for provenance studies of terrigenous sedimentary rocks: European Union of Geosciences (EUG 9), 23-24 March 1997, Strasbourg (Franse), Abstract 65/4P16, p. 597 